\title{
Traumatic wound dehiscence after penetrating keratoplasty
}

\author{
Özlem Barut Selver, M.D., Melis Palamar, M.D., Sait Eğrilmez, M.D., Ayşe Yağcı, M.D.
}

Department of Ophthalmology, Ege University Faculty of Medicine, İzmir-Turkey

\begin{abstract}
BACKGROUND: The aim of this study was to evaluate risks and consequences of traumatic wound dehiscence after penetrating keratoplasty (PK).

METHODS: Data regarding 34 eyes of 34 patients who were treated for traumatic wound dehiscence after PK between 1995 and 2014 were studied. Patient records were reviewed for type and time of insult, corrected distance visual acuity (CDVA), clinical presentation signs, operative method, and outcome.

RESULTS: The interval between PK and trauma ranged from I month to 100 months, with median of 14 months. Median age at trauma was 31.5 years (range: 5-8I years). Wound dehiscence occurred at donor-recipient interface in all patients. In $58.8 \%$ of patients, extent of dehiscence was $\geq 6$ clock hours. Most frequent type of trauma was blunt trauma by hand/finger ( $35.2 \%$ ). Median CDVA before and just after trauma were 0.5 logMAR (range: 0.1-3.0 logMAR) and 3.0 logMAR (range: 0.7-3.0 logMAR), respectively. Wound dehiscence was managed with primary wound closure in all patients. Most frequent additional surgical procedure was anterior vitrectomy (26.4\%). Anatomical globe loss occurred in 2 patients. Median CDVA was 0.7 logMAR (range: $0.1-3.0$ logMAR) at final visit. Most common complication after primary suturation was graft failure (23.5\%). Graft remained clear in $67.6 \%$ of patients.
\end{abstract}

CONCLUSION: Traumatic wound dehiscence is one of the potentially devastating postoperative complications that can occur following PK. Prognosis depends on existence and severity of additional anterior/posterior segment damage. In order to prevent this catastrophic condition, patients should be warned against ocular trauma after undergoing PK.

Keywords: Keratoplasty; ocular trauma; wound dehiscence.

\section{INTRODUCTION}

One possible and potentially devastating postoperative complication of penetrating keratoplasty (PK), the standard full thickness corneal transplantation technique, is wound dehiscence secondary to trauma. ${ }^{[1]}$ Surgical wound after PK makes cornea more vulnerable to trauma than intact cornea due to decreased strength of graft-host interface. ${ }^{[2,3]}$

Incidence of traumatic wound dehiscence after PK has been reported as between $0.6 \%$ and $5.8 \% .^{[1,4-10]}$ This complication generally occurs within first 2 years after PK, and may lead to delayed visual rehabilitation and increased risk of corneal graft edema and rejection. ${ }^{[4,6,11-14]}$

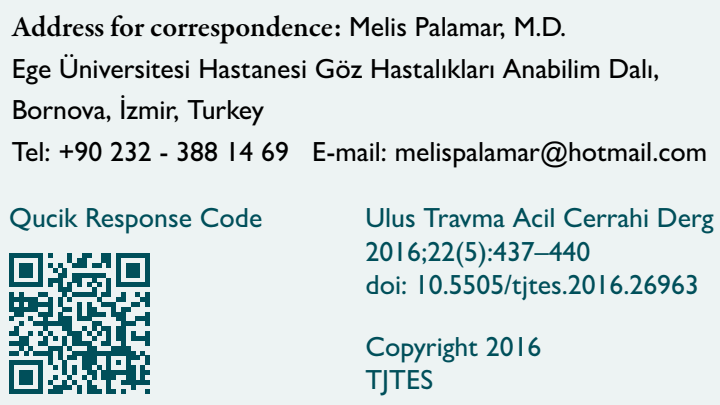

Our department, which has more than 20 years of experience, maintains a large corneal transplantation database. This study retrospectively analyzed incidence, predisposing factors, graft survival, and visual outcome of traumatic wound dehiscence following PK to compare these data and comment on results in the literature.

\section{MATERIALS AND METHODS}

Retrospective data analysis of patients who had corneal wound dehiscence after PK between 1995 and 2014 was performed. Records of patients were reviewed for age, gender, PK indication, type and time of insult, suture presence, accompanying anterior and posterior segment damage, corrected distance visual acuity (CDVA) (as measured with Snellen chart), operative methods, and surgical outcome. Statistical analysis was performed using SPSS software for Windows version 15.0 (SPSS Inc.; Chicago, Illinois, USA) and Microsoft Office Excel (Microsoft Corp.; Redmond, Washington, USA). Shapiro-Wilk test was performed to test normality of data. Statistical analyses were done using frequency tables, nonparametric tests, and logistic regression analyses. A value of $\mathrm{p}<0.05$ was accepted as statistically significant. 


\section{RESULTS}

Incidence of graft dehiscence was 2.6\% (34 eyes) among I 300 PK eyes. Male to female ratio was I.6:I. Most frequent primary PK indication was keratoconus (26.4\%). Other common indications were perforation sequel $(23.5 \%)$ and pseudophakic bullous keratopathy (PBK) (14.7\%). The interval between PK and trauma ranged from I month to 100 months, with median of 14 months. Median age at time of trauma was 31.5 years (range: 5-8I years). Number of patients under age of 18 was 10 (29.4\%). Wound dehiscence occurred at donor-recipient interface in all patients, and $70.5 \%$ of graft dehiscences occurred in postoperative 18 months. In most eyes (58.8\%), extent of wound dehiscence was $\geq 6$ clock hours. Most frequent type of trauma was minor blunt trauma with hand or finger (35.2\%). Other causes of trauma were major blunt trauma, falling, and intentional assault. Prior to trauma, 17 eyes were phakic, 15 eyes were pseudophakic, and 2 eyes were aphakic. Seventeen (50\%) eyes had either crystalline lens/intraocular lens dislocation or expulsion upon impact of trauma. Seven phakic and 5 pseudophakic patients (35.2\%) had lens expulsion, I phakic and 4 pseudophakic patients (14.7\%) had lens dislocation (Fig. Ia, b). Iris or vitreous prolapse was detected in 10 eyes (29.4\%) (Fig. 2a, b). At time of trauma sutures were present in $22(64.7 \%)$ eyes (Fig. 3). Eight (75\%) of 12 eyes without sutures had graft dehiscence within the first 6 months of suture removal. According to logistic regression analysis, presence of sutures and amount of dehiscence were not related $(p>0.05)$.

Median CDVA before and right after trauma were 0.5 logMAR (range: 0.1-3.0 logMAR) and 3.0 logMAR (range: 0.7-3.0 log$M A R)$, respectively $(p<0.05)$. Graft dehiscence was managed with primary wound closure in all eyes. Most frequent additional surgical procedure was anterior vitrectomy (29.4\%). Posterior segment damage was noted as suprachoroidal hemorrhage (I patient), macular hemorrhage (I patient), or retinal detachment (3 patients). Anatomical globe loss occurred in 2 eyes of these 5 patients (I suprachoroidal hemorrhage patient and I retinal detachment patient who also had endophthalmitis afterward). Two retinal detachment patients had a final CDVA of 3.0 logMAR and I retinal detachment patient had a final CDVA of I.0 logMAR. Median CDVA was 0.7 logMAR (range: 0.1-3.0 logMAR) at final visit. Regression analysis was performed to identify predictors of visual acuity loss such as gender, age, time interval between trauma and keratoplasty, suture presentation, dehiscence amount, and lens status. None of the factors were found to be related $(p>0.05)$.

Most common complication after primary suturation was graft failure (23.5\%). Mean follow up period was $24.9 \pm 21.0$ months (range: 6-110 months). Graft was clear in $67.6 \%$ of patients at final visit.
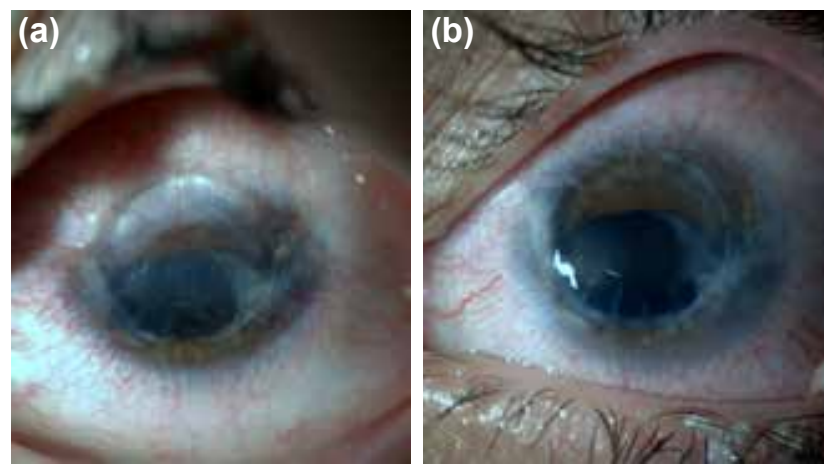

Figure 1. (a) Traumatic wound dehiscence caused by finger trauma in a 24-year-old female patient: intraocular lens dislocation from superior graft-host interface, (b) anterior segment appearance after primary suturation.
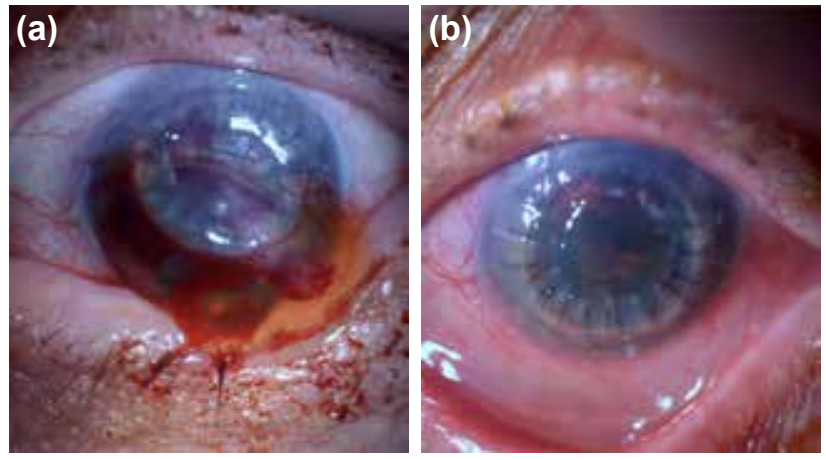

Figure 2. (a) Traumatic wound dehiscence caused by hand trauma in a 70-year-old male patient: iris and vitreous prolapses, (b) anterior segment appearance after primary suturation.

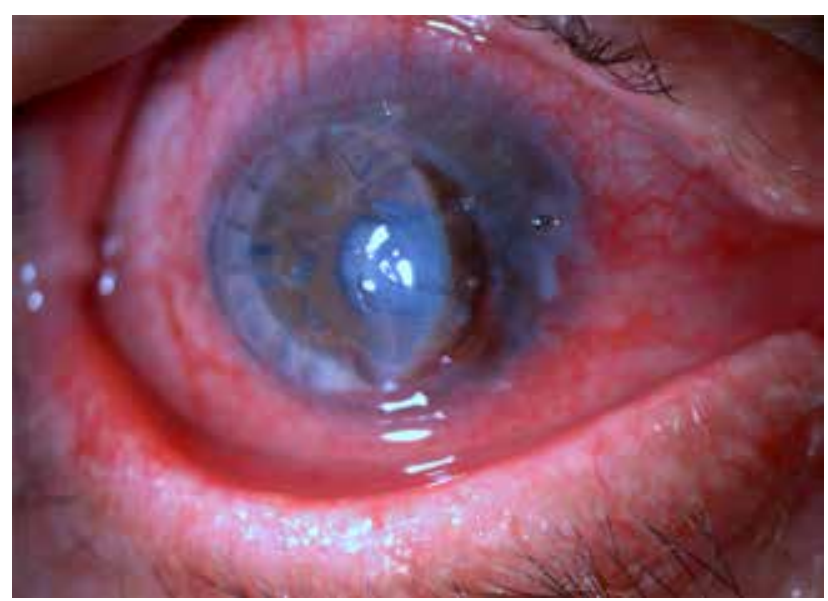

Figure 3. Traumatic wound dehiscence caused by finger trauma in a 63-year-old male patient. Graft dehiscence occurred 4 months after keratoplasty surgery while sutures were present.

\section{DISCUSSION}

Corneal wound integrity depends on corneal sutures during the first few weeks after surgery. In sutured limbal wounds, reorganization of collagen is required for wound site to regain tensile strength. ${ }^{[1,15]}$ In several studies it has been reported that corneal scar tissue at graft-host interface never recovers strength of normal corneal tissue. ${ }^{[4,16,17]}$ Factors that impair 
corneal wound healing and cause wound weakness at grafthost interface after PK include avascular characteristics of cornea, use of non-inflammatory suture material, increased intraocular pressure, and prolonged steroid treatment. For this reason, wound dehiscence after trauma commonly occurs at graft-host junction. ${ }^{[2-4,7,9,10,16]}$ In the present study, all graft dehiscences occurred at graft-host interface, a finding consistent with the literature.

In this case series, incidence of graft dehiscence was 2.6\% (34 eyes) among I 300 PK eyes, which is also consistent with the literature..$^{[1,4-10]}$ Incidence was reported to be $1.5 \%$ in our previous case series consisting of 6 eyes in 398 PK eyes. ${ }^{[18]}$ The first year -- and especially the first month -- is reported to be the most vulnerable period for traumatic wound dehiscence after PK. Risk progressively decreases over next 18 months. $[10,11,19]$ Suture removal weakens wound integrity and risk for wound dehiscence increases significantly. ${ }^{[10]}$ In the present series, $70.5 \%$ of graft dehiscences occurred in postoperative 18 months, and $23.5 \%$ of graft dehiscence took place within the first 6 months of suture removal. Some authors report that grafts with intact sutures tend to have a smaller degree of dehiscence, but we did not find such a relationship in this case series.

Most common indications for PK among patients who developed wound dehiscence were keratoconus and PBK. In the present study, the most common indication was keratoconus (26.4\%), which is consistent with the literature. ${ }^{[20,21]}$ The next most common indications were perforation sequel $(23.5 \%)$ and PBK (14.7\%).

Anterior or posterior segment damage such as iris prolapse; crystalline lens or intraocular lens extrusion; vitreous loss; corneal endothelium damage, which can cause graft failure; choroidal hemorrhage; and total disruption of intraocular contents may accompany wound dehiscence at time of trauma. ${ }^{[22]}$ In the present series, percentage of iris or vitreous prolapse was (29.4\%). Crystalline lens or intraocular lens extrusion was positive in $35.9 \%$ of patients. Incidence of lens extrusion has been reported to be $25 \%$ to $100 \%$ in several studies, and present result is consistent with the literature. $[4,6,7,16]$ Graft failure was detected in $23.5 \%$ of patients. Primary determinant of final visual acuity is force of trauma and status of posterior segment. ${ }^{[23]}$ Posterior segment involvement (5 patients) in present series was instances of suprachoroidal hemorrhage, macular hemorrhage, and retinal detachment. Two of these patients had anatomical globe loss and 3 had a final CDVA of I.0 logMAR or worse.

Even if graft appears to be edematous or opaque, immediate wound repair in traumatic wound dehiscence after PK is recommended. ${ }^{[16,17]}$ General anesthesia is a requirement for these traumatic patients, as any blink or blepharospasm movement could cause expulsive hemorrhage. ${ }^{[2]}$ Graft dehiscence was managed with primary wound closure under general anesthesia for all patients in current study.
Clear corneal graft percentage after traumatic wound dehiscence was reported to be $20 \%$ to $100 \%$ in several studies. ${ }^{[7,25]}$ Consistent with the literature, $67.6 \%$ of traumatic wound dehiscence patients with preserved globe anatomy in present study had clear grafts.

Principal limitation to this study was retrospective format. Records that were not designed for the study and an absence of data on potential confounding factors are the principle disadvantages of retrospective format.

In conclusion, even years after surgery, traumatic corneal graft dehiscence is one of the most devastating complications that can occur following PK. Patients should be warned that eyes that had PK will always be vulnerable to injury. For high-risk patients, such as young males, who made up a large proportion of current study (6I\%); children, who comprise nearly $30 \%$ of our patients; people who work with sharp objects, etc., eye shields or goggles are recommended for protection after grafting and just after suture removal.

Conflict of interest: None declared.

\section{REFERENCES}

1. Bowman RJ, Yorston D, Aitchison TC, McIntyre B, Kirkness CM. Traumatic wound rupture after penetrating keratoplasty in Africa. Br J Ophthalmol 1999;83:530-4. Crossref

2. Farley MK, Pettit TH. Traumatic wound dehiscence after penetrating keratoplasty. Am J Ophthalmol 1987;104:44-9. Crossref

3. Raber IM, Arentsen JJ, Laibson PR. Traumatic wound dehiscence after penetrating keratoplasty. Arch Ophthalmol 1980;98:1407-9. Crossref

4. Agrawal V, Wagh M, Krishnamachary M, Rao GN, Gupta S. Traumatic wound dehiscence after penetrating keratoplasty. Cornea 1995;14:601-3.

5. Elder MJ, Stack RR. Globe rupture following penetrating keratoplasty: how often, why, and what can we do to prevent it? Cornea 2004;23:77680. Crossref

6. Rehany U, Rumelt S. Ocular trauma following penetrating keratoplasty: incidence, outcome, and postoperative recommendations. Arch Ophthalmol 1998;116:1282-6. Crossref

7. Tseng SH, Lin SC, Chen FK. Traumatic wound dehiscence after penetrating keratoplasty: clinical features and outcome in 21 cases. Cornea 1999;18:553,8.

8. Kartal B, Kandemir B, Set T, Kugu S, Keles S, Ceylan E, et al. Traumatic wound dehiscence after penetrating keratoplasty. Ulus Travma Acil Cerrahi Derg 2014;20:181-8. Crossref

9. Rohrbach JM, Weidle EG, Steuhl KP, Meilinger S, Pleyer U. Traumatic wound dehiscence after penetrating keratoplasty. Acta Ophthalmol Scand 1996;74:501-5. Crossref

10. Lam FC, Rahman MQ, Ramaesh K. Traumatic wound dehiscence after penetrating keratoplasty-a cause for concern. Eye (Lond) 2007;21:114650. Crossref

11. Gasset AR, Dohlman CH. The tensile strength of corneal wounds. Arch Ophthalmol 1968;79:595-602. Crossref

12. Perry HD, Donnenfeld ED. Expulsive choroidal hemorrhage following suture removal after penetrating keratoplasty. Am J Ophthalmol 1988;106:99-100. Crossref 
13. Brown SI, Tragakis MP. Wound dehiscence with keratoplasty: complication of the continuous-suture technique. Am J Ophthalmol 1971;72:115-6. Crossref

14. Binder PS, Abel R Jr, Polack FM, Kaufman HE. Keratoplasty wound separations. Am J Ophthalmol 1975;80:109-15. Crossref

15. Gliedman ML, Karlson KE. Wound healing and wound strength of sutured limbal wounds. Am J Ophthalmol 1955;39:859-66. Crossref

16. Topping TM, Stark WJ, Maumenee E, Kenyon KR. Traumatic wound dehiscence following penetrating keratoplasty. $\mathrm{Br} \mathrm{J}$ Ophthalmol 1982;66:174-8. Crossref

17. Pettinelli DJ, Starr CE, Stark WJ. Late traumatic corneal wound dehiscence after penetrating keratoplasty. Arch Ophthalmol 2005;123:853-6.

18. Egrilmez S, Uzunel UD, Yagci A. Ocular Trauma Following Keratoplasty. MN Ophthalmology 2004;11:200-4.

19. Elder MJ, Stack RR. Globe rupture following penetrating keratoplasty: how often, why, and what can we do to prevent it? Cornea 2004;23:776-80.
20. Nagra PK, Hammersmith KM, Rapuano CJ, Laibson PR, Cohen EJ. Wound dehiscence after penetrating keratoplasty. Cornea 2006;25:1325. Crossref

21. Cosar CB, Sridhar MS, Cohen EJ, Held EL, Alvim Pde T, Rapuano CJ, et al. Indications for penetrating keratoplasty and associated procedures, 1996-2000. Cornea 2002;21:148-51. Crossref

22. Oshry T, Lifihitz T. Traumatic wound dehiscence after corneal graft. Ophthalmic Surg Lasers 2001;32:470-3.

23. Das S, Whiting M, Taylor HR. Corneal wound dehiscence after penetrating keratoplasty. Cornea 2007;26:526-9.

24. Kaslow O, Gollapudy S. Anesthetic considerations for ocular and maxillofacial trauma. In: Varon AJ, Smith CE, eds. Essentials of Trauma Anesthesia. Cambridge, UK: Cambridge University Press 2012. p. 198-219.

25. Foroutan AR, Gheibi GH, Joshaghani M, Ahadian A, Foroutan P. Traumatic wound dehiscence and lens extrusion after penetrating keratoplasty. Cornea 2009;28:1097-9. Crossref

\section{ORİJINAL ÇALIŞMA - ÖZET}

\section{Penetran keratoplasti sonrası travmatik yara ayrilması}

\section{Dr. Özlem Barut Selver, Dr. Melis Palamar, Dr. Sait Eğrilmez, Dr. Ayşe Yağcı}

Ege Üniversitesi Tıp Fakültesi, Göz Hastalıkları Anabilim Dalı, İzmir

AMAÇ: Bu çalışmanın amacı penetran keratoplasti sonrası oluşan travmatik yara ayrılmasının risklerini ve olası sonuçlarını değerlendirmektir.

GEREÇ VE YÖNTEM: Çalışmaya kliniğimizde 1995-20। 4 yılları arasında penetran keratoplasti sonrası travmatik yara ayrılması gelişen 34 hastanın 34 gözü dahil edilmiştir. Hastaların kayıtları, travmanın tipi ve zamanı, en iyi düzeltilmiş görme keskinliği (ElDGK), başvuru anındaki bulgular, uygulanan cerrahi girişim ve sonuçları açısından incelendi.

BULGULAR: Penetran keratoplasti cerrahisi ve travma arasında geçen süre bir ay ile 100 ay arasında değişmekle beraber median I4 aydı. Travma sırasındaki median yaş, 3 I.5 (5-8I) yıldı. Tüm hastalarda yara ayrııması, donör-alıcı ara yüzünde meydana gelmişti. Hastaların \%58.8'inde ayrılmanın büyüklüğü, altı saat kadranı veya daha genişti. En sık travma, parmak veya elle olan künt travmaydı (\%35.2). En iyi düzeltilmiş görme keskinliği median değeri, travma öncesinde 0.5 logMAR (0.1-3.0), travmadan hemen sonraki muayenede ise 3.0 logMAR (0.7-3.0) idi. Yara ayrılması, tüm hastalarda primer sütürasyon ile tamir edildi. En sık uygulanan ilave cerrahi prosedür, ön vitrektomiydi (\%26.4). İki hastada anatomik glob kaybı meydana geldi. Son vizitte, EIDGK median değeri 0.7 logMAR (0.1-3.0) idi. Primer sütürasyon sonrası en sık rastlanan komplikasyon greft yetmezliğiydi (\%23.5). Hastaların \%67.6'sında greft saydamdı.

TARTIŞMA: Travmatik yara ayrılması, penetran keratoplasti sonrası ortaya çıkabilen en yıkııı komplikasyonlardandır. Prognoz, eşlik eden ön ve arka segment hasarlanmasına bağıdır. Bu kötü durumdan korunmak amacıyla penetran kornea nakli geçiren hastalar, cerrahi sonrası olası göz travmalarına karşı uyarılmalıdır.

Anahtar sözcükler: Keratoplasti; oküler travma; yara ayrılması. 